University of Michigan Law School

University of Michigan Law School Scholarship Repository

1921

\title{
Declaratory Judgment - Declaring Rights under the Guise of Granting an Injunction
}

\author{
Edson R. Sunderland \\ University of Michigan Law School
}

Available at: https://repository.law.umich.edu/articles/1103

Follow this and additional works at: https://repository.law.umich.edu/articles

Part of the Civil Procedure Commons, and the State and Local Government Law Commons

\section{Recommended Citation}

Sunderland, Edson R. "Declaratory Judgment-Declaring Rights under the Guise of Granting an Injunction." Mich. L. Rev. 20 (1921): 218-9.

This Response or Comment is brought to you for free and open access by the Faculty Scholarship at University of Michigan Law School Scholarship Repository. It has been accepted for inclusion in Articles by an authorized administrator of University of Michigan Law School Scholarship Repository. For more information, please contact mlaw.repository@umich.edu. 
DECLARATORY JUDGMENT-DeCLARING RIGHTS UNDER THE GUISE OF GRANTING AN INJUNCTION-It has often been held that a party may obtain a judicial determination of his rights in respect to legislation alleged to be invalid, by means of an application to a court of equity for an injunction restraining the enforcement of the statute. Ex parte Young (1907) 209 U. S. 123, is the leading case of this type. There, a railroad rate statute was involved, which required compliance by all railroad companies in the state, under the threat of heavy penalties. The railroad actually violated the provisions of the statute after an injunction had been obtained by a stockholder restraining the company from complying, and prosecution for the violation was prevented by an injunction against the attorney general. The latter injunction, it must be noted, was an effective and appropriate ordeì, because acts of violation were in fact taking place which would otherwise have called forth action by the attorney general. The injunction could not, therefore, be looked upon as anything but a genuinely operative remedy. Trtax v. Raich (Igr5) 239 U. S. 33, Michigan Salt Works v. Baird (1913) 173 Mich. 655, and other like cases, were all similar in this respect. In each, the act for which the prosecution was feared had been committed, and the injunction was employed as a protection against a presently possible prosecution.

But let it be supposed that the case is one where no violation of the statute has taken place and where none is contemplated until after the court has passed upon its validity. Is there anything to enjoin? The attorney general cannot prosecute because nothing has been done upon which to base a prosecution. Can the attorney general be enjoined from prosecuting before any violation or even threat of violation has occurred?

In Anzway v. Grand Rapids Ry. Co. (I920) 2II Mich. 592, an effort was made to obtain a decision from the court as to whether a contract could legally be made which the plaintiff alleged that he was desirous of making. The plaintiff feared the penalties of a statute. He had no intention of entering into the proposed contract unless he was first assured by the court that he would not be liable for the penalty. He asked for a declaration of rights, under the Declaratory Judgment Act, and got it, but the supreme court held that at this stage there was no controversy pending, and that the declaration was only a decision on a moot question and therefore invalid. Apparently it was the view of the supreme court of Michigan that until the plaintiff did some act upon which the penal statute could operate, there could be no judicial question. In this view of the proceedings the addition of a prayer for an injunction against the attorney general would have added nothing to the substance of the case, for no prosecution was possible because there was no violation of the statute, either actual or threatened. The infirmity in the case was held to go much deeper than a mere procedural failure to add a suitable prayer. The court held that there was no cause of action in existence 
which could be employed by the plaintiff in a court of justice.

A case identical on its facts with the Amway Case has just been decided by the United States District Court for the Western District of Washington, three $j$ udges sitting and concurring. Terrace v. Thompson (1921) 274 Fed. 841. In that case the owners of certain land wished to lease it to a Japanese. A statute known as the Alien Land Bill in terms prohibited such a lease under heavy penalties, but the parties believed the apparent prohibition was not legally effective. They were not willing, however, to make the lease unless the court first assured them that it could safely be done, and they joined as complainants in a bill in equity, making the attorney general a party defendant, and asked for an injunction restraining the defendant from prosecuting under the statute. The court cited Ex parte Young, supra, as authority for taking jurisdiction, and the rights of the parties were determined. As in the Anway Case, no act had been done by the complainants contrary to the statute. No prosecution was therefore possible, and the complainants made it clear in their bill that they did not propose to render themselves liable to any prosecution. The attorney general was therefore enjoined from an impossibility, viz., from suing on a cause of action which not only did not exist but was not threatened or even contemplated. The injunction was therefore essentially premature, and apparently served only as a cloak to hide a mere declaration of rights. The court held that where parties contemplate entering into a contract which may or may not amount to a violation of a penal statute, the court will, in advance of any act on their part which could be deemed wrongful, pass upon their rights and tell them whether their contemplated action will or will not be a violation of the act. This is a pure declaration of rights, and it was made in this case as an exercise of inherent judicial power, without any authorizing statute.

E. R. S. 